\title{
System of Taxation and Its Conceptual Foundations
}

\author{
Musa Sh. Basnukaev ${ }^{*}$ \\ Chechen State University, Russian Federation; Corresponding email: basnukaev@hotmail.com
}

Nokh Kh. Tokaev

North Ossetian State University named after Kosta Levanovich Khetagurov

\section{Doi:10.5901/mjss.2015.v6n6s7p35}

\section{Abstract}

The article is devoted to the identification of the features of formation and functioning of the taxation system. The emphasis is made on refining its differences from the tax system, on the functions they perform. Also, the study clarifies the problem of validity of the tax exemptions based on current budgets and strategic objectives, the combination of influential factors and feasibility of changes depending on the profitability of the economy and its development. Authors analyze and evaluate the gradual change in the tax practice in Russia.

Keywords: tax, taxation, tax system, tax exemptions, tax payments, budget revenues

\section{Introduction}

Creation, development and functioning of the tax system is a complex process and it cannot get a decent development unless the criteria are clearly defined, the mechanisms of implementation and goal-setting. Current purpose of tax exemptions to the budgets of different levels reflect the need to build their respective income. Withdrawal of the surplus in the form of payment of the budget is carried out in a planned manner and reflects its required expediency within those state revenue sources, which created by the level of economic development. Unjustified economic exemption of a part of surplus in the budget may be a measure contrary to sound logic of taxation, no matter how it is justified by the reasons of fiscal expediency. We believe that in contrast to the current unjustified tax exemptions revenues to the budget, the world, including the Russian practice, has developed and uses, firstly, the methods of improvement of the general system of taxation, secondly, a differentiated approach to setting tax rates, and thirdly, many forms of taxes, given that each of them has a reasonable determination of the unique base source.

\section{The Tax System and the System of Taxation}

The systemic approach towards resolution of ongoing issues in taxation is crucial. In this context, however, one should fully take into account that the current and strategic objectives of the system of implemented tasks may not correspond (Dvorkovich, 2003). The proximity of these objectives to each other, their interrelatedness, certainly will largely depend on (at different stages) a combination of factors of influence and those conditions that will dictate (i.e. demand) the state of the economy, its profitability and prospects. Sustainable economic development, accompanied by rising incomes, creates conditions for the systemic unity of the implemented objectives of taxation. If the economic space of the country is dominated by the ineffective means of using productive resources, it is expected the negative consequences of excessive tax exemptions, justified by the presence of increasing budgetary needs. However, the strategic goals of improving the taxation system could be implemented by improving management tools, which include: the differentiation of taxes (i.e. their diversity); changes in tax rates; the use of tax incentives; synchronization of fiscal actions in the process of socioeconomic development with a focus on targeted measures to stimulate economic activity, etc.

The issue of unjustified expectations of formation of a tax system without the active involvement of public authorities, however, should not cause doubt that there is some 'ownership' of taxes to the state (Polyak \& Romanov, 2010; Romanovsky \& Vrublevskaya, 2010; Chernik, 2010). In a nationwide practice, this feature is confirmed by the fact that the government has formed a regulating conceptual framework, the provisions of the structure and functioning conditions of the tax system, which is embodied in the Tax Code of the Russian Federation (2015). After removal of the 
revenues in the budget in the form of tax revenues, combined they to turn into the state budget fund. Forms of exemption of taxes in the budget, their volume indicators, certainly affect the nature of their use, but not fully. Effective tax exemptions process begins when determining sources of tax revenues, tax rates and tax payment procedure. Issues of budgetary allocation and use of tax revenues obtain independence, are regulated by the state, but only through a reverse effect may have an impact on the tax system.

Budget use of tax revenues, as such, cannot be the determinant of performance indicators forming the tax (Basnukaev \& Bamataliev, 2014; Tokayev \& Hadzhianidi, 2012). In the least, it should not be. The mechanism of formation of tax reflects many contributing factors (commonly known or not known in full). The main thing, in our view, is to be clear of what is the economy capable of in taxation. Placing pressure on the economy by taxation and forcing it to provide high-volume revenues is a doomed affair, as is often evidenced by the low level of tax collection and tax violations, including hidden income, undeclared income, etc.

Building a stable and resistant to the necessary changes tax system is impossible without solving the following tasks:

- Must have formed a common vision and evaluation component of the tax potential as the initial basis for the formation of a structured system of taxation and the tax system (the latter cannot be a simple set of taxes that are not sufficiently valued in the interrelations and correlation);

- Developed a strictly reasoned position, according to which the system of taxation and the tax system are in a single legal field of interrelation that involves the establishment of norms and rules, which are the starting point for implementing the principles of regulation in the system of tax relations;

- The basis of tax federalism (taking into account the state system) is elaborated, approved (by law) and developed in the basis of reasonable assurance, which enables to ensure the budget revenues at all levels of the unified budget system, to solve the problems of balance and consolidation;

- Measures of the tax liability are considered and observed, embodying both the fairness in setting tax and the goal setting, as well as the objectives that are implemented by taxation.

System of taxation is not a given set of certain taxes for all time (Shatalov, 2008). It is essential to take into account that, in accordance with the objectives embodied in taxation, all the rules of tax practice can and should change. Thus, it will take into account its unity, rationality and efficiency. Required a flexible tax system that promotes quality improvement of the system of taxation. Unsystematic approach will inevitably be characterized by lack of established legal bases of taxation, lack of an integrated approach to the tasks being carried out and as a result, the growth of tax problems. Single establishment of tax legislation does not determine all components of the system: all has to take place in real and this is the complexity of the multidimensional nature of the action. One should not forget that in the context of past and further developing market relations, a set of taxes and the level of tax revenues, their collection becomes a real influence on the formation of the entire system of distributive relations in the economy.

The taxation system and methods embodied in it can have an impact on the collection of taxes and on the effectiveness of mechanisms for their functional performance. At the same time, one needs to fully take into account that tax planning is intended to be as clear and reasonably measured basis of the parameters of taxes and focused ordering in the taxation system. Planned definition and legislative establishment of each of the taxes implies the assessment and consideration of both the tax base and opportunities to rationalize the level of taxation on the amount set (in monetary terms), correlated to the aforementioned base (i.e. the tax rate being set per unit of the tax base). The planned calculation of the amount of the tax is twofold: firstly, the accuracy of the assessment of the tax base, and secondly, certainty of the feasibility of withdrawal as income tax in the budget.

Tax systems, mainly used in the modern states, are based on the fact that each tax should be not only estimated, but also formalized. In this context, formulation is not just a simple formality account, but also the legal certainty of the tax in the system. We shall recall once again that the tax system is a certain set of taxes, calculated, approved and raised in favor of the country's budget. The well-known German financier Dieter Bryummerhoff considering these problems, stressed the following: "The amount of revenue from the tax is determined mainly by registration of tax. This includes the selection and delimitation of subjects of taxation, tax base and rates. Finally, there are also important the conditions for payment of the tax. The tax rate is the correlation of the base and the amount of tax" (Bryummerhoff, 2002, p. 187). Given the additional interpretation of the 'preponderance' in determining the size, one should probably keep in mind the estimated share of tax in the tax potential. The distribution of income is influenced by many factors, among them the majority are determining the tariff of the taxes. In a narrower sense, it covers the issues of in-depth knowledge of the situation of certain types of taxable income in total income, which is implemented in the economy.

We also emphasize that the market system of taxation on the overall assessment of economists-scientists, is 
based on the principle of equal distribution of the tax burden (Polyak \& Romanov, 2008; Sidorovich, 2007). However, it should be seen as a requirement of economic reality, but not reality initially set in the tax system. The fact that there is a relationship between the amount of income and economically feasible volumes of tax revenues cannot be denied. Moreover, this relationship should be viewed in the context of interdependence and as widely as possible, versatile. Reducing the overall tax burden, given an increase in revenues produced, is a normal variant of taxation and the tax system should be able to consolidate it. At the same time, the rationality of the norms of taxation is provided in different ways, methods and techniques, but it is essential to take into account changing circumstances of functioning of the taxation system. For example, the unjustified reduction of the state share in the income of the economy (i.e. limiting the size of the budget) is also unacceptable, as well as the excessive tax exemption of the generated revenue. The imperfection of the state system can give rise to negative trends of raising tax revenues to the budget and unjustified changes of measures and methods of taxation. At the same time increases the probability of default those tasks that have not been assessed correctly. Taxes are raised in the budget not for the disproportionate and inefficient use of resources, but in order to meet the needs of formed systemic needs, which are not covered in any other way (Nikolov \& Tokaev, 2007; Sozonova \& Tokaeva, 2004).

In each case (of specific tax), the issue of the tax rates, which cannot be properly identified and set in the system of tax payments should be repeatedly coordinated with the general requirements of the efficient functioning of the tax system. If the latter is faltering, manifests itself in a negative way for the economy, in the fiscal-economic stability, then it is necessary to address to the problems of the tax system itself. Only the establishment of a certain number of taxes, their rates (i.e. the percentage of the amount of tax to the taxable base), changes in tax rates cannot solve the indicated problems. The objectives of the taxation system, as a rule, are fundamental and it should not be interpreted narrowly via fiscal way: to collect more or cut taxes. The most important is the effect of a functioning system for the production of income in the economy (encouraging or discouraging), the distribution of income (use of the principle of uniformity), the improvement of employment and the avoidance of speculative price promotion. These issues can primarily be solved by the tax system and its requirements are feasible in the mechanisms and tools that the state uses, adjusting tax and budget relations.

System approach in the development of taxation becomes better if its impact on the tax system is enhanced. In our opinion, it is necessary and possible under the regulation of the rights and obligations of the taxpayer, but with a parallel improvement (i.e. justification) of the responsibilities, rights and duties of tax and other bodies dealing with tax regulation (see. Art. 21 of the Tax Code, Art. 30-37, section 3 of the Tax Code). Experience in the development, adoption and streamline of the system of taxation, which had and has a place in modern Russia, certainly deserves both positive and critical evaluation.

\section{Establishment of the Tax and Taxation Systems of the Modern Russia}

Russia, on the one hand, made certain steps towards the development of a unique tax system in 1991-1992, considering the positive experience of world practice. It should be noted that the appeal was also to the classical tax theories and concepts that were developed for a long period of time, based on market-based approaches to solving the problems that arise. On the other hand, at present time the Russian practice has not found a balanced solution of formation and effective functioning of the tax system, which would fully correspond the adequate state of the economy, the nature of its market changes and transformations. The system of taxation in Russia has not only advantages, but also significant drawbacks. We shall recall that in 1991 Russia introduced a complicated three-tier tax system with fees and taxes by the federal, regional and local levels. They were established: the federal -15 , regional -3 , local -21 , the total of 39 . In addition to taxes and fees, instead of the collapsed system of state social insurance, the extra-budgetary state funds were created, having their own norms of deductions (i.e. Pension Fund, Health Insurance Fund, Social Insurance Fund, and the Employment Fund).

Promptly formed tax system in 1991, later has undergone some changes, but it set the conditions for the functioning of the tax system as for a set of taxes, and the level of rates. Lacking sufficient economic justification, rules and regulations of the fiscal tax were not only overcomplicated, but also impossible to implement to the extent that it required the development of an economic system. In other words, an excessive expansion of the specific functions of individual taxes and the overall tax system led to inability of stimulating economic development while remaining fiscal measures. As a consequence, the economy was 'oppressed' by rising prices, inflation. Individual taxes initially appeared to be ultra-high (e.g. value-added tax, income tax, profit tax on businesses, income tax on individuals) and as a result, the total load of taxes on the economy and its revenues was substantial in scale, which is confirmed by the table 1 . Russian tax practice since 1991 retains the high taxation of wages, including industrial enterprises, which negatively affects the 
stimulation of employment and the results of their labor, the interests of entrepreneurs in the growth of wages. In the same context, there is a practice hidden wages paid which are not taxed (often in collusion of individuals and employers), as well as reduction of the positive impact of this practice on the formation of income from production operations. Latter, in our opinion, should be assessed as a negative factor of large-scale economic nature.

Table 1. The level of taxation in 1991 (nominal rates and the rates to the actual amendment)

\begin{tabular}{lcc}
\hline Tax and deduction & $\begin{array}{c}\text { Nominal } \\
\text { rate }\end{array}$ & $\begin{array}{c}\text { Actual rate adjusted for VAT } \\
\text { (for the domestic market) }\end{array}$ \\
\hline Value added tax & $28 \%$ & $28.0 \%$ \\
Corporate income tax & $32 \%$ & $41.0 \%$ \\
Income tax on individuals & $12 \%$ & $15.4 \%$ \\
Contributions to the Pension Fund & $60 \%$ & $76.8 \%$ \\
Contributions to the Compulsory Medical Insurance Fund & $29 \%$ & $37.1 \%$ \\
Contributions to the Social Insurance Fund & $5.40 \%$ & $6.9 \%$ \\
Contributions to the Employment Fund & $3.60 \%$ & $4.6 \%$ \\
Road tax & $1.50 \%$ & $1.9 \%$ \\
Tax on the maintenance of housing and objects of social-cultural sphere & $2.50 \%$ & $3.2 \%$ \\
Enterprise assets tax & $1.50 \%$ & $1.9 \%$ \\
The total burden on the wage bill with a minimum wage & $51.50 \%$ & $1.3 \%$ \\
The total burden on the wage bill with a maximum wage & $88.70 \%$ & $65.9 \%$ \\
\hline
\end{tabular}

Source: compiled by the authors based on data from the Federal Tax Service

The data in table 1 also show that the tax system initially adopted in the Russia had contradictory regulatory base of taxes, which was bound to generate high overall load on the wage bill both in its minimum and maximum values. Scholars point out that the same practice has spread to the value added tax, which largely contributed to the growth of prices, and further promotion of inflation (Tokayev \& Hadzhianidi, 2012). Since 1991, the established tax regime for more than $90 \%$ of Russian trade and industrial enterprises was set that initially inflated nominal rates in reality turned out to be at very high levels (80-90\%).

The total system of taxation has formed a practice (that is largely retained by 2015), when the harmonization of turnover taxes and value-added tax (with their high rates) created an unacceptable tax burden, and little executable and little dependable from the actual financial results in the real economy. To those entrepreneurs engaged in production economies a situation of growing financial difficulties is gradually created. Thus, the target reference points are 'washed out' from the system of taxation and this has contributed to reduction of the effectiveness of the income of enterprises, as the criterion of the importance of maintaining their liquidity in taxation. Taxation did not enable to introduce the elements of financial stability of enterprises, as a result of economic growth and development.

Formed in 1991, the tax system, as we have noted, mostly remained unchanged, although having certain changes that deserve individual assessment. Table 2 summarizes the evidence for a gradual softening of interest rates on the main taxes.

Table 2. Changes in tax rates according to the periods

\begin{tabular}{|c|c|c|c|}
\hline Tax and deduction & \multicolumn{3}{|c|}{ Initial rate Current rate Comments } \\
\hline Value added tax & $28 \%$ & $18 \%$ & $\begin{array}{l}\text { The initial rate set in } 1993 \text { was } 20 \% \text {, in } 2004 \text { it became } 18 \% \text {. The procedure for quarterly } \\
\text { payments since } 2004 \text { remianed unchanged }\end{array}$ \\
\hline Corporate income tax & $32 \%$ & $20 \%$ & $\begin{array}{l}\text { The initial rate set in } 1995 \text { was } 38 \% \text {, from } 1996 \text { to } 2001 \text {, the rate was } 35 \% \text {, since } 2002 \text { it } \\
\text { was } 24 \% \text {, and } 20 \% \text { in } 2009 \text {. Advance tax payment procedure is maintained since } 1992 \\
\text { In 1992, the maximum rate was reduced to } 40 \% \text {; from } 1993 \text { to } 1995 \text {, it was lowered to }\end{array}$ \\
\hline Income tax on individuals & $12 \%-60 \%$ & $13 \%$ & $\begin{array}{l}30 \% \text {; from } 1996 \text { to } 1998 \text { the rate was 35\%; in } 1999-42 \% \text {, in } 2000 \text { over } 30 \% \text {. Finally, } \\
\text { since } 2001 \text { the consistent rate is } 13 \%\end{array}$ \\
\hline Road tax & $2.50 \%$ & $0 \%$ & It was reduced to $1 \%$ in 2001 and completely abolished in 2003 \\
\hline $\begin{array}{l}\text { Tax on the maintenance of } \\
\text { housing and objects of social- } \\
\text { cultural sphere }\end{array}$ & $1.50 \%$ & $0 \%$ & It was canceled in 2001 \\
\hline Enterprise assets tax & $1 \%$ & $2.2 \%$ & Already since 1993 , the rate was increased to $2 \%$, and since 1998 remained unchanged \\
\hline
\end{tabular}

Source: compiled by the authors based on data from the Federal Tax Service 
Characteristics of changes in tax rates were influenced by the reasons being formed by the tax system with the introduction of norms of deductions to the state budget social funds (see figure 1 ). The rate of contributions to the pension fund remained stable (29\%) since 1993 by 2000. In the period of 2001-2004 it decreased by one percent (28\%), and then from 2005 by 2010 it was 20\%. In 2011, it increased by 6\% (26\%) and in 2012-2015 it stabilized at 22\%. A different alignment of changes occurred at the rate of contributions to the Federal Compulsory Medical Insurance Fund (FCMIF) and contribution rates in the Social Insurance Fund of the Russian Federation (SIFRF). These changes only partly affected positively to the functioning of the tax system, and as shown by the data in figure 1, they were associated with limited allocations to these social funds of the state. To this we add that the deductions in all these funds come on fund of accrued wages in enterprises and must be paid monthly.

\begin{tabular}{|c|c|c|c|c|c|c|c|c|c|c|}
\hline \multirow[b]{2}{*}{ Year } & \multicolumn{3}{|c|}{$\mathrm{PF}$} & \multicolumn{3}{|c|}{ FCMIF } & \multicolumn{3}{|c|}{ SIFRF } & \multirow{2}{*}{$\begin{array}{l}\text { EF } \\
\text { Rate }\end{array}$} \\
\hline & Rate & Limit & $\begin{array}{c}\text { Rate above } \\
\text { limit }\end{array}$ & Rate & Limit & $\begin{array}{c}\text { Rate } \\
\text { above } \\
\text { limit }\end{array}$ & Rate & Limit & $\begin{array}{c}\text { Rate above } \\
\text { limit }\end{array}$ & \\
\hline 1992 & $31.6 \%$ & & & $3.8 \%$ & & & $5.4 \%$ & & & $1.0 \%$ \\
\hline 1993 & $29.0 \%$ & & & $3.6 \%$ & & & $5.4 \%$ & & & $2.0 \%$ \\
\hline 1904 & $29.0 \%$ & & & $3.6 \%$ & & & $5.4 \%$ & & & $2,0 \%$ \\
\hline 1955 & $29.0 \%$ & & & $3.6 \%$ & & & $5.4 \%$ & & & $1.5 \%$ \\
\hline 1996 & $29.0 \%$ & & & $3.6 \%$ & & & $5.4 \%$ & & & $1.5 \%$ \\
\hline 1997 & $29.0 \%$ & & & $3.6 \%$ & & & $5.4 \%$ & & & $1.6 \%$ \\
\hline 1998 & $29.0 \%$ & & & $3.6 \%$ & & & $5.4 \%$ & & & $1.5 \%$ \\
\hline 1999 & $29.0 \%$ & & & $3.6 \%$ & & & $5.4 \%$ & & & $1.5 \%$ \\
\hline 2000 & $29.0 \%$ & & & $3.6 \%$ & & & $5.4 \%$ & & & $1.5 \%$ \\
\hline \multirow[t]{3}{*}{2001} & $28.0 \%$ & 100000 & $15.8 \%$ & $3.6 \%$ & 100000 & $2.0 \%$ & $4.0 \%$ & 100000 & $2.2 \%$ & $0.0 \%$ \\
\hline & & 300000 & $7.9 \%$ & & 300000 & $1.0 \%$ & & 300000 & $1.1 \%$ & \\
\hline & & 600000 & $5.0 \%$ & & 800000 & 10600 & & 600000 & 11700 & \\
\hline \multirow[t]{3}{*}{2002} & $28.0 \%$ & 100000 & $15.8 \%$ & $3.6 \%$ & 100000 & $2.0 \%$ & $4.0 \% \%$ & 100000 & $2.2 \%$ & $0.0 \%$ \\
\hline & & 300000 & $7.9 \%$ & & 300000 & $1.0 \%$ & & 300000 & $1.1 \%$ & \\
\hline & & 600000 & $20 \%$ & & 600000 & पणठ0ण & & 600000 & 11700 & \\
\hline \multirow[t]{3}{*}{2003} & $28.0 \%$ & 100000 & $15.8 \%$ & $3.6 \%$ & 100000 & $2.0 \%$ & $4.0 \%$ & 100000 & $2.2 \%$ & $0.0 \%$ \\
\hline & & 300000 & $7.9 \%$ & & 300000 & $1.0 \%$ & & 300000 & $1.1 \%$ & \\
\hline & & 600000 & $2.0 \%$ & & पण0ण0ण & 10600 & & 600000 & 11700 & \\
\hline \multirow[t]{3}{*}{2004} & $28.0 \%$ & 100000 & $15.8 \%$ & $3.6 \%$ & 100000 & $2.0 \%$ & $4.0 \%$ & 100000 & $2.2 \%$ & $0.0 \%$ \\
\hline & & 300000 & $7.9 \%$ & & 300000 & $1.0 \%$ & & 300000 & $1.1 \%$ & \\
\hline & & 600000 & $2.0 \%$ & & 600000 & 10600 & & 600000 & 11700 & \\
\hline \multirow[t]{2}{*}{2005} & $20 \%$ & 280000 & $7.9 \%$ & $2.8 \%$ & 280000 & $1.0 \%$ & $3.2 \%$ & 280000 & $1.1 \%$ & $0.0 \%$ \\
\hline & & 600000 & $2.0 \%$ & & 600000 & 11040 & & 600000 & 12480 & \\
\hline \multirow[t]{2}{*}{2006} & $20 \%$ & 280000 & $7.9 \%$ & $2.8 \%$ & 280000 & $1.0 \%$ & $3.2 \%$ & 280000 & $1.1 \%$ & $0.0 \%$ \\
\hline & & 600000 & $2.0 \%$ & & 600000 & 11040 & & 600000 & 12480 & \\
\hline \multirow[t]{2}{*}{2007} & $20 \%$ & 280000 & $7.9 \%$ & $3.1 \%$ & 280000 & $1.1 \%$ & $2.9 \%$ & 280000 & $1.0 \%$ & $0.0 \%$ \\
\hline & & 600000 & $2.0 \%$ & & 600000 & 12200 & & 600000 & 11320 & \\
\hline 2010 & $20 \%$ & 415000 & $0.0 \%$ & $3.1 \%$ & 415000 & $0.0 \%$ & $2.9 \%$ & 415000 & $0.0 \%$ & $0.0 \%$ \\
\hline 2011 & $26 \%$ & 463000 & $0.0 \%$ & $5.1 \%$ & 463000 & $0.0 \%$ & $2.9 \%$ & 463000 & $0.0 \%$ & $0 . \% \%$ \\
\hline 2012 & $22 \%$ & 512000 & $10.0 \%$ & $5.1 \%$ & 512000 & $0.0 \%$ & $2.9 \%$ & 512000 & $13.0 \%$ & $6.0 \%$ \\
\hline 2013 & $22 \%$ & 568000 & $10.0 \%$ & $5.1 \%$ & 568000 & $0.0 \%$ & $2.9 \%$ & 568000 & $0.0 \%$ & $0.0 \%$ \\
\hline 2014 & $22 \%$ & 624000 & $10.0 \%$ & $5.1 \%$ & 624000 & $0.0 \%$ & $2.9 \%$ & 624000 & $0.0 \%$ & $0.0 \%$ \\
\hline 2015 & $22 \%$ & 711000 & $700 \%$ & $5.1 \%$ & 711000 & $5.1 \%$ & $2.9 \%$ & 670000 & $0.0 \%$ & $0.0 \%$ \\
\hline
\end{tabular}

Figure 1. Dynamics of changes in payments to the state budget funds of social contributions

Source: Compiled by the authors based on data from the Ministry of Finance

\section{Conclusion}

Thus, the following conclusions should be summarized, the implementation of which will contribute to the improvement of the taxation system, and, as a result, the functioning of the tax system in Russia. Firstly, the system is designed (this is an economic requirement for its development) to be focused on the gradual introduction of sound and acceptable (by the criterion of the efficiency) tax deductions to the budgets of different levels - with a reduction in the tax load on its homolographic potential. Secondly, there was initially (in 1991) and continues to be a lack of differentiation of tax dedications to the budget, which would stimulate the taxpayers to earn large income as well as undergo fair and complete payments. Thirdly, taxes and their set in the system of operations require a much more attention, given the uneven and frequent changes in prices, inflation. Fourthly, the deficiencies inherent in the tax system that do not meet the requirements of economic growth and development, make appropriate of further improvement of tax legislation, including in the direction of the search for new solutions for the creation of additional conditions to strengthen the security of real producers, from both the government and market influences. 


\section{References}

Basnukaev, M.Sh., \& Bamataliev, A-V.B. (2014), Personal income tax: the factors forming the base, regulatory framework and completeness of ensuring the revenue of the budget. Journal of North Ossetian State University, 4, 1-10.

Bryummerhoff, D. (2002), The theory of public finance (the translation of the seventh German edition). Vladikavkaz: Pioneer Press.

Chernik, D.G. (2010), Taxes: textbook for universities, 5th edition, revised and expended. Moscow: UNITY-DANA.

Dvorkovich, A.V. (2003), The taxation of added value: economic nature, practice, problem solving. Tax Policy and Practice, 6, 67-78.

Nikolov, V.V., \& Tokaev, N.Kh. (2007), Tax violations in the system of economic relations. Vladikavkaz: Olymp.

Polyak, G.B., \& Romanov, A.N. (2008), Taxes and taxation. Moscow: Unity.

Polyak, G.B., \& Romanov, A.N. (2010), Taxes and taxation. Moscow: Unity.

Romanovsky, M.V., \& Vrublevskaya, O.V. (2010), Taxes and taxation, $5^{\text {th }}$ edition. St. Petersburg: Peter.

Shatalov, S.O. (2008), On measures of tax incentives for priority areas of economic development of Russia. Finance, 8, 1-4.

Sidorovich, A. (2007), The course of economic theory. Moscow: Moscow State University Press.

Sozonova, S.V., \& Tokaeva, T.I. (2004), Economic and market-based mechanism for improving tax control. Vladikavkaz: North Ossetian State University.

Tax Code of the Russian Federation (2015). Parts one and two. Moscow: Elit.

Tokayev, N.Kh, \& Hadzhianidi, F.G. (2012), The taxation of added value: economic nature, practice, problem solving. Vladikavkaz: Olymp. 